\section{Contribution of natural milk culture to microbiota, safety and hygiene of raw milk cheese produced in alpine malga}

Rosaria Lucchini, ${ }^{1}$ Barbara Cardazzo, ${ }^{2}$ Lisa Carraro, ${ }^{2}$ Michele Negrinotti, ${ }^{3}$ Stefania Balzan, ${ }^{2}$ Enrico Novelli, ${ }^{2}$ Luca Fasolato, ${ }^{2}$ Franco Fasoli, ${ }^{3}$ Giovanni Farina $^{1}$

${ }^{1}$ Institute for Experimental Veterinary Medicine of Venezia, Section of Trento; ${ }^{2}$ Department of Comparative Biomedicine and Food Science, University of Padua, ${ }^{3}$ Operative Unit of Hygiene and Veterinary Public Health, Agency for Healthcare Services of Autonomous Province of Trento, Italy

\section{Abstract \\ Processing of alpine milk in malga} farms is carried out under conditions that can favor contamination by coliforms, coagulase-positive staphylococci, or pathogens such as Listeria monocytogenes. With the aim to improve the hygienic characteristics and safety of cheese produced in four malga farms the use of lyophilized Natural Milk Culture prepared with selected strains was tested.. Two cheesemaking tests were carried out in the same day always starting from the same milk: in the first case following the malga recipe that uses either Natural Whey Culture or without the addition of a starter, in the second one using a Natural Milk Culture. Cheesemaking were carried out in four malga farms located in the west area of Trentino region within the same week. For hygienic and safety evaluation, aerobic colony count, coagulase-positive staphylococci, Escherichia coli, staphylococcal toxins, Listeria monocytogenes, and Salmonella spp, $\mathrm{pH}$ and $a_{w}$ were determined in raw milk from evening and morning milking, curd in vat, curd after extraction and two months-ripened cheese. Pathogens or toxins, high values of coagulase-positive staphylococci and $E$. coli were not found in cheese samples. However, in the curd coagulase-positive staphylococci reached values almost of $5 \mathrm{Log} \mathrm{CFU} / \mathrm{g}$ in the two malga without starter cultures. The use of Natural Milk Culture reduced E. coli counts. In addition, DNA was extracted from cheese samples and from Natural Milk Culture and the composition of the microbial community determined by Next Generation Sequencing method. The determination of cheese microbial communities demonstrated that the use of Natural Milk Culture exerted different effects in the different $m a \lg a$, in any case preserving bacterial biodiversity.

\section{Introduction}

In the recent years the interest of consumers toward mountain dairy products has greatly increased and several studies have been carried out on milk and cheese obtained under the unique Alpine conditions. The Alps are a $1300 \mathrm{~km}$ mountain chain, located in the north of Italy (Povolo et al., 2013). The ancient tradition of producing raw cow's milk cheese in small dairy farms is common across the Alpine region, including Italian, Austrian, and Swiss Alps. Small farms called malga (or alm in general) are located between 1000 and $2500 \mathrm{~m}$ above sea level and during summer season house the cattle that from the valley are moved to alpine pastures. Both milk collection and cheesemaking are carried out in the malga and cheese production follows a procedure that varies for each malga, according structural conditions, quality of raw material, hygienic state from milk collection, cheesemaking, to ripening. All such characteristics might either favor or prevent the presence of coliforms, coagulase-positive staphylococci (CPS) and, pathogens such as L. monocytogenes (Lm) Contamination can be recurrent, with severe economic losses and risks for food safety. Contamination of dairy products with pathogens can be counteracted by milk pasteurization and/or by using lactic bacterial cultures (LABs) that help curdling and can compete with pathogens preventing their growth (Lucchini 2015, Topisirovic et al., 2006).

Normally, in malga farms, commercial starters are not used and microbial fermentation is spontaneous, carried out by the autochthonous microbiota or by adding their own production whey culture (Natural Whey Culture, NWC) (Carafa et al., 2016). While the use of commercial starters may reduce the richness and variability of the cheese microbiota and level off the typical organoleptic characteristics in traditional ripened cheeses, it allows to obtain cheese with desired and predictable properties. In addition, the use of commercial starters improves the standardization of cheesemaking procedures reducing the risk of contamination with pathogens or spoilers (Montel et al., 2014; Mucchetti and Neviani, 2006).

According to the EFSA Report (2014), $5.4 \%$ of foodborne outbreaks on 763 occurring in 21 European countries are attributed to the consumption of contaminated
Correspondence: Barbara Cardazzo, Department of Comparative Biomedicine and Food Science, University of Padova, Viale dell'Università, 16, Legnaro, 35020, Padova, Italy.

Tel.: +39.049.8272965 - Fax: +39.049.8272973. E-mail: barbara.cardazzo@unipd.it

Key words: Cheese; Hygiene; Natural Milk Culture; NGS, malga.

Contributions: the authors contributed equally.

Conflict of interest: the authors declare no potential conflict of interest.

Funding: none.

Received for publication: 31 July 2017.

Revision received: 10 November 2017.

Accepted for publication: 11 November 2017.

This work is licensed under a Creative Commons Attribution-NonCommercial 4.0 International License (CC BY-NC 4.0).

(C) Copyright R. Lucchini et al., 2018

Licensee PAGEPress, Italy

Italian Journal of Food Safety 2018; 7:6967

doi:10.4081/ijfs.2018.6967

cheeses. The pathogens most frequently implicated are: Lm, Staphylococcus aureus, Salmonella spp., Ec O157: H7 and more rarely Mycobacterium avium subsp. paratubercolosis (Kousta et al., 2010). Many authors describe $S$. aureus as the main cause for food poisoning associated with dairy products, especially for not ripened cheese (Rosengren et al., 2010) and raw milk cheese (Brooks et al., 2012; De Buyser et al., 2001; Duquenne et al., 2010).

Good hygienic practices to reduce risks cannot be always implemented, considering that malga facilities are often not sufficiently equipped. Therefore, further options for contamination containment (such as technological practices) should be considered to prevent risks related to the consumption of raw cow's milk cheese.

The purpose of the study was to experiment the use of Natural Milk Culture (NMC) in raw milk processing and to evaluate its effects on microbial composition and on hygiene and safety characteristics of cheese. The obtained results may then be used to identify corrective actions that may be applied by the operators to ensure consumer safety. 


\section{Materials and Methods}

\section{Cheesemaking}

The preparation of experimental NMC was performed by Bioagro Laboratory, Veneto Agricoltura (Thiene, Italy). Three strains were isolated from malga milk and curd, tested for technological characteristics and identified by RAPD-PCR methods as two different strains of Streptococcus thermophilus and a strain of Lactobacillus delbrueckii subsp. Bulgaricus (Andrighetto et al., 2002). Lyophilized NMC containing the three selected strains cultivated in milk was produced and tested in a previously experimental study (Paternolli et al., 2014).

Traditional mountain malga cheese is a semicooked cheese made by mixing raw cow's milk from both morning- and overnight skimmed milk collected the previous evening. Curdling occurs at $35-38^{\circ} \mathrm{C}$, milk coagulation is obtained using a commercial rennet, then the curd is cooked at about $43-45^{\circ} \mathrm{C}$ for at least 30 minutes. The curd is cut into rice-like particles and kept at the same temperature until pouring into molds. After two days of brine salting, wheels of cheese are ripened for two months in a dedicated malga room at 12$18^{\circ} \mathrm{C}$ on wooden shelves, turning them over periodically. Ripening is then completed in a storeroom down in the valley for at least 9-12 months. Such traditional cheese making process was followed in four different malga farms (called M1, M2, M3 and M4), located in the west area of Trentino region. In each farm two cheesemaking procedures were followed: the first one following the malga recipe, the second one adding experimental NMC to promote coagulation, together with a commercial rennet. In malga $\mathrm{M} 1$ and $\mathrm{M} 2$ the recipe included the use of NWC, made from malga cheesemaker every day and added to drive primary fermentation. In M3 and M4, microbial fermentation was spontaneous, being started and carried on by autochthonous bacteria until the end of the ripening $(\mathrm{N})$.

\section{Sampling}

Samples of bulk raw milk, curd from vat, curd after extraction, and two-months ripened cheese were collected. All milk, curd, and cheese samples were analyzed within 24 hours using standard microbiological methods. An aliquot from all cheese samples was frozen and stored at $-80^{\circ} \mathrm{C}$ for NGS analysis. At the same time of cheese sampling, the following cheese quality parameters were evaluated: odor, colour, obvious defects, presence and shape of holes in the cheese.

\section{pH and water activity detection}

$\mathrm{pH}$ and water activity $\left(a_{w}\right)$ were performed according to ISO 2917:1999 and ISO 21807:2004, respectively. Sample of milk (evening and morning bulk milk, after mixing in vat, before addition of starter cultures, before rennet), samples of curd (curd in vat and after extraction) and two-months ripened cheese were tested for $\mathrm{pH}$. Samples of curd and two-months ripened cheese were analysed for $a_{w}$.

\section{Culture-dependent analysis}

In order to evaluate cheese for safety and hygienic microbiology criteria, the following analyses were performed. (A) Salmonella spp by real time PCR (iQcheck $^{\mathrm{TM}}$ Salmonella spp II kit Bio Rad, Hercules, CA, USA) with validation certificate AFNOR BRD 07/06-07/04, (B) Listeria monocytogenes by real time PCR (iQ-check ${ }^{\mathrm{TM}}$ Listeria monocytogenes II kitBio Rad, Hercules, CA, USA) with validation certificate No: AFNOR BRD 07/1004/05, (C) staphylococcal enterotoxins according to the European Union Reference Laboratory for CPS protocol with the VIDAS SET 2 test (bioMerieux, Marcy l'Etoile, France); (D) aerobic colony count (ACC) according to ISO 4833-1:2013, (E) Escherichia coli $(\mathrm{Ec})$ according to ISO 16649-2:2001, (F) coagulase-positive staphylococci according to ISO 68882:1999/Amd 12003.

Samples of bulk raw milk and samples of curd in vat and after extraction were tested applying A,B,D,E, F analysis. Cheese samples were tested for all of analysis (AF). The results obtained from the different samples were calculated according to the ISO 7218:2007/Amd 1 2013, corrected version 2014/04/15.

\section{Culture-independent analysis on cheese}

The extraction of DNA from $150 \mathrm{mg}$ of cheese and from the pellet obtained from $1 \mathrm{~mL}$ of NMC was carried out with Invisorb Spin Tissue Mini Kit (Invitek $\mathrm{GmbH}$, Berlin, Germany) following the instructions provided by the kit manufacturer. At the end of the procedure, DNA was eluted in $50 \mu \mathrm{L}$ of Elution Buffer. The concentration and purity of DNA were analysed using a NanoDrop ND-1000 (Thermo Scientific, Massachusetts, United States). To determine the exact quantity to be used for NGS library construction, an aliquot of diluted (1:200) DNA template was amplified in a final volume of $10 \mu \mathrm{L}$ containing $5 \mu \mathrm{L}$ of Platinum SYBR Green qPCR Supermix UDG (Invitrogen, Life Technologies, Monza, Italy), and $0.25 \mu \mathrm{L}$ of each primer $331 \mathrm{~F}$ and $797 \mathrm{R}(10 \mu \mathrm{M})$ (Nadkarni et al, 2002). For NGS sequencing, the V3-V4 regions of the 16S rRNA gene were amplified using the primers $331 \mathrm{~F}$ 5'-TCCTACGGGAGGCAGCAGT-3' and 797F 5'GGACTACCAGGGTATCTAATCCTGTT (Nadkarni et al., 2002). The primers were modified with a forward overhang (5'T C G T C G GCA GCG T CA GAT G T G TATAAGAGACAG-[1ocus-specific sequence]-3') and a reverse overhang (5'GTCTCGTGGGCTCGGAGATGTGTATAAGAGACAG-[locus-specific sequence]-3'), which was necessary for dual index library preparation. PCR products were purified using AMPure purification kit (Agenourt, Beverly, MA). After purification, every sample was quantified using the Qubit ${ }^{\circledR} \quad 2.0$ fluorometer (Invitrogen). The quality of amplicon libraries was tested using an Agilent 2100 Bioanalyzer (Agilent Technologies, Palo Alto, CA). Libraries were pooled and sequenced by BMR Genomics (Padova, Italy) using a Miseq Illumina 2x300 version 3. Sequence data were deposited in SRA database (accession number SRP109249). Raw sequences data were filtered, trimmed, and merged through with CLC Genomics Workbench. Qiime version 1.9 was used to perform full analysis from operational taxonomic units (OTUs) picking to statistical analysis (Caporaso et al., 2010). The pick_closed_reference_otus wrapper (minimum similarity 0.8) was used for OTU picking with Greengenes $13.8 \mathrm{v}$ as reference database. Sequences were then filtered with filter_samples_from_otu_table.py to remove any OTU observed in the blank control. OTUs represented by less than $0.005 \%$ of total sequences were discarded (Bokulich et al.,2013). To characterize microbial communities and to perform functional analyses, the following wrappers have been employed: assign taxonomy (to assign Greengenes taxonomy to OTUs), make_otu_table (to create biom file with OTUs and taxonomy), compute_core microbiome (to calculate the core microbiome), summarize_taxa_ through_plots (to produce taxonomical files and charts), alpha_rarefaction and beta_diversity_through_plots (to assess respectively alpha- and beta-rarefaction diversity indices), principal_coordinates.py (to compare groups of samples based on phylogenetic distance metrics). ANOVA was performed using CALYPSO version 7.18

\section{Results and Discussion}

\section{pH values}

The $\mathrm{pH}$ of products obtained by the addition of NMC from different malga 
farms showed a similar pattern and the curd reached values between 5.2 and 5.4 (as shown in Table 1). The curd obtained with the $\mathrm{M} 1$ recipe showed $\mathrm{pH}$ values not lower than 6 , a circumstance potentially hazardous in presence of pathogens or enterotoxin producer Staphylocccus aureus (Schelin et al., 2011). In M2 acidification curves are similar, but it should be pointed out that milk had very low $\mathrm{pH}$ values, as can be seen in Figure 1A. In M3 and M4, pH in curd without starter cultures was much higher than that obtained with NMC. Acidification is important for milk coagulation and to counteract the growth of undesirable microorganisms. In fact, low $\mathrm{pH}$ values and their rapid decrease, as well as the presence of lactic acid deriving from lactic bacteria metabolism, may inhibit the growth of S. aureus (Schelin et al., 2011) and $E$. coli (Presser et al., 1997). Also, the production of enterotoxins is counteracted by low level of $\mathrm{pH}$ values and the presence of lactic acid (Schelin et al., 2011).

\section{Culture-dependent analysis}

Listeria monocytogenes and Salmonella spp were not found in milk, curd and cheese samples. Moreover, staphylococcal enterotoxins were not detectable in two months ripened cheeses.

The ACC in raw milk were from 4.0 to 6.7 Log CFU/mL, as shown in Table 1. M1 raw milk presented $\mathrm{ACC} 30^{\circ} \mathrm{C}$ values less than $5 \mathrm{Log} \mathrm{CFU} / \mathrm{mL}$ and it complied with the requirements laid down in European Regulation 853/2004, Section IX, Chapter I, point 3 related to raw milk criteria $[\mathrm{ACC}$ $30^{\circ} \mathrm{C}<5 \mathrm{Log} \mathrm{CFU} / \mathrm{mL}$, rolling geometric average over a two-month period, with at least two samples per month (European Commission, 2004)], assessment of these parameters done before the cattle were moved from the valley to alpine pastures). On the opposite, the other three malga farms showed values higher than $5 \mathrm{Log}$ $\mathrm{CFU} / \mathrm{mL}$. In M2, ACC values were very high in both evening and morning bulk milk, 6.7 Log CFU/mL and 6.1 Log $\mathrm{CFU} / \mathrm{mL}$ respectively, while in $\mathrm{M} 3$ and $\mathrm{M} 4$ only evening bulk milk, (5.8 Log CFU/mL and 6.1 Log CFU/mL respectively). These results likely suggest insufficient hygiene practices either in the milking process and in refrigeration tank sanitization, as well as an insufficient rapid cooling of milk.

CPS contamination in raw milk was similar in all four malga farms with mean values of $1.7 \pm 0.5 \mathrm{Log} \mathrm{CFU} / \mathrm{mL}$ in evening bulk milk and $2.8 \pm 0.4 \mathrm{Log} \mathrm{CFU} / \mathrm{mL}$ in morning bulk milk. CPS were not detectable in any two months-ripened cheese. CPS developed during curdling and after extraction of the curd, not exceeding 6 Log CFU/g in all four malga farms, an important threshold for staphylococcal enterotoxins development (Bennett et al., 1983). There was no measurable difference for CPS in cheesemaking process using NMC or malga recipe. However in M4, CPS values for curd in vat (3.6 Log CFU/g ) and after extraction (3.8 Log CFU/g) made with NMC were $1 \log \mathrm{CFU} / g$ lower than CPS values in samples produced with $\mathrm{N}$ recipe (4.5 Log CFU/g and 4.6 Log CFU/g respectively). This is in agreement with a role of acidification in reducing CPS counts (Schelin et al., 2011), as in M4 products a lower $\mathrm{pH}$ in NMC was observed (Figure 1B). E. coli was not detectable in any sample from M1. In M2, E. coli reached similar values during cheese production either with NMC or M2 recipe (NWC). In M3, E. coli developed with similar values in N_cheesemaking compared to NMC cheesemaking, although in NMC cheese samples E. coli counts were $1.8 \mathrm{Log} \mathrm{CFU} / \mathrm{g}$, lower than N_cheese sample (3.3 Log CFU/g). In M4

Table 1. Microbiological counts, $\mathrm{pH}$, water activity and biodiversity of Malga samples.

Samples and analysis M1_NMC M1_NWC M2_NMC M2_NWC M3_NMC M3_N M4_NMC I4 N

\section{Evening bulk milk}

\begin{tabular}{|c|c|c|c|c|c|c|c|c|}
\hline $\begin{array}{l}\mathrm{ACC} \\
\mathrm{CPS} \\
\mathrm{Ec} \\
\mathrm{pH}\end{array}$ & $\begin{array}{l}4.0 \\
1.6 \\
\text { nd } \\
6.7\end{array}$ & $\begin{array}{l}4.0 \\
1.0 \\
\text { nd } \\
6.7\end{array}$ & $\begin{array}{l}6.7 \\
1.6 \\
4.4 \\
5.7\end{array}$ & $\begin{array}{l}6.7 \\
1.6 \\
4.4 \\
5.7\end{array}$ & $\begin{array}{l}5.8 \\
2.1 \\
1.6 \\
6.6\end{array}$ & $\begin{array}{l}5.8 \\
2.1 \\
1.6 \\
6.6\end{array}$ & $\begin{array}{l}6.1 \\
2.3 \\
4.0 \\
6.5\end{array}$ & $\begin{array}{l}5.4 \\
1.0 \\
3.9 \\
6.6\end{array}$ \\
\hline $\begin{array}{l}\text { Morning bulk milk } \\
\text { ACC } \\
\text { CPS } \\
\text { Ec } \\
\text { pH } \\
\text { pH Milk in vat } \\
\text { pH Milk before starter } \\
\text { pH Milk before rennet } \\
\text { pH Starting curdling }\end{array}$ & $\begin{array}{l}4.3 \\
2.8 \\
\text { nd } \\
6.7 \\
6.5 \\
6.5 \\
6.5 \\
6.3\end{array}$ & $\begin{array}{l}4.3 \\
2.4 \\
\text { nd } \\
6.7 \\
6.5 \\
6.5 \\
6.3 \\
6.0\end{array}$ & $\begin{array}{l}6.1 \\
3.4 \\
2.1 \\
6.6 \\
6.1 \\
6.1 \\
6.1 \\
6.0\end{array}$ & $\begin{array}{l}6.1 \\
3.4 \\
2.1 \\
6.6 \\
6.2 \\
6.1 \\
6.1 \\
6.2 \\
\end{array}$ & $\begin{array}{l}4.3 \\
2.8 \\
1.6 \\
6.7 \\
6.5 \\
6.5 \\
6.5 \\
6.8\end{array}$ & $\begin{array}{l}4.3 \\
2.8 \\
1.6 \\
6.7 \\
6.8 \\
6.8 \\
6.8 \\
6.9\end{array}$ & $\begin{array}{l}4.2 \\
2.5 \\
1.0 \\
6.7 \\
6.9 \\
6.9 \\
6.8 \\
6.8\end{array}$ & $\begin{array}{l}4.1 \\
2.6 \\
1.6 \\
6.6 \\
7.0 \\
6.9 \\
6.9 \\
7.0\end{array}$ \\
\hline $\begin{array}{l}\text { Curd in vat } \\
\text { CPS } \\
\text { Ec } \\
\text { pH }\end{array}$ & $\begin{array}{l}4.1 \\
\text { nd } \\
5.3\end{array}$ & $\begin{array}{l}4.0 \\
\text { nd } \\
6.1\end{array}$ & $\begin{array}{l}3.6 \\
4.8 \\
5.2\end{array}$ & $\begin{array}{l}4.0 \\
5.0 \\
5.5\end{array}$ & $\begin{array}{l}4.7 \\
3.8 \\
5.4\end{array}$ & $\begin{array}{l}4.7 \\
4.0 \\
6.2\end{array}$ & $\begin{array}{l}3.6 \\
4.8 \\
5.4\end{array}$ & $\begin{array}{l}4.5 \\
6.0 \\
6.5\end{array}$ \\
\hline $\begin{array}{l}\text { Curd after extraction } \\
\text { CPS } \\
\text { Ec } \\
\text { pH }\end{array}$ & $\begin{array}{l}4.1 \\
\text { nd } \\
5.3\end{array}$ & $\begin{array}{l}4.0 \\
\text { nd } \\
6.1\end{array}$ & $\begin{array}{l}3.9 \\
5.0 \\
5.2\end{array}$ & $\begin{array}{l}4.0 \\
5.1 \\
5.3\end{array}$ & $\begin{array}{l}4.8 \\
4.0 \\
5.4\end{array}$ & $\begin{array}{l}4.7 \\
4.1 \\
6.1\end{array}$ & $\begin{array}{l}3.8 \\
5.1 \\
5.3\end{array}$ & $\begin{array}{l}4.6 \\
6.2 \\
6.3 \\
\end{array}$ \\
\hline $\begin{array}{l}\text { Two months ripened cheese } \\
\text { ACC } \\
\text { CPS } \\
\text { E. coli } \\
\text { pH } \\
\text { Water activity } \\
\text { Biodiversity index (observed species) }\end{array}$ & $\begin{array}{c}7.8 \\
\text { nd } \\
\text { nd } \\
5.2 \\
0.95 \\
88.1\end{array}$ & $\begin{array}{c}7.4 \\
\text { nd } \\
\text { nd } \\
5.5 \\
0.95 \\
114.9\end{array}$ & $\begin{array}{c}7.4 \\
\text { nd } \\
1,6 \\
5.5 \\
0.95 \\
90.6\end{array}$ & $\begin{array}{c}7.1 \\
\text { nd } \\
1.0 \\
5.6 \\
0.96 \\
114.8\end{array}$ & $\begin{array}{c}7.4 \\
\text { nd } \\
1.8 \\
5.7 \\
0.96 \\
117.8\end{array}$ & $\begin{array}{c}6.5 \\
\text { nd } \\
3.3 \\
5.7 \\
0.97 \\
107\end{array}$ & $\begin{array}{c}7.5 \\
\text { nd } \\
1.0 \\
5.3 \\
0.94 \\
88.5\end{array}$ & $\begin{array}{c}7.0 \\
\text { nd } \\
4.5 \\
5.3 \\
0.94 \\
113.3\end{array}$ \\
\hline
\end{tabular}

nd = not detectable; $\mathrm{ACC}, \mathrm{CPS}$ and $\mathrm{Ec}$ are intended $\mathrm{Log} \mathrm{CFU} / \mathrm{g}$. 
evening raw milk showed an important contamination from E. coli (4.0 Log CFU/mL). In the early stages of curdling, Ec in NMC_curd were $4.8 \mathrm{Log} \mathrm{CFU} / \mathrm{mL}$, while in N_curd were $6.0 \mathrm{Log} \mathrm{CFU} / \mathrm{mL}$. Values increased in the curd after extraction, respectively $5.1 \mathrm{Log} \mathrm{CFU} / \mathrm{g}$ and $6.2 \mathrm{Log}$ $\mathrm{CFU} / \mathrm{g}$, and decreased in two monthsripened cheese. In N_cheese Ec were 4.5 Log CFU/g, higher than NMC cheese (1 Log CFU/g, Figure 1C)

\section{Evaluation of cheese quality}

After two months of ripening M1 cheeses were similar, but NWC_cheese had an elastic paste, less rich in holes than M1 NMC cheese. M2 NMC samples showed defects in the cheesemaking as a non-homogeneous color in the center was present with an evident fracture due to an intense fermentation. The external surface of both M2_cheeses had an unpleasant odor probable due to the storage in a poorly ventilated and very humid room. Both M3 cheese revealed numerous small holes typical of the growth of coliforms derived from the starting milk and from poor hygiene during cheesemaking, defects that were much more evident in M3 NWM cheese. Moreover, the external surface of both M3 cheese smelled of animal and ammonia, due to a poor hygiene of the wooden shelves or in the storage room. M4_NMC_cheese showed a typical aspect of propionic fermentation, while M4_N cheese showed an excessive fermentation not well distributed within the cheese, probable due to sudden temperature changes after curd extraction. Intense fermentation is very likely due to poor hygienic quality of milk. In particular, both M3 and M4_NMC_cheeses resulted considerably different from $\mathrm{N}$ cheeses and the appearance of cheese reflected the load of Ec that suggests fecal contamination during milking and/or cheesemaking (McSweeney PLH, 2007).

\section{Culture-independent analysis on cheese}

Microbial community profiles of cheese samples were assessed by $16 \mathrm{~S}$ amplicon sequencing. A total of 245 OTUs with $97 \%$ similarity were obtained after OTU picking and the coverage index is $>0.99$ for all samples. As expected the phylum Firmicutes dominates the community in all samples (from 64.9 to $99.5 \%$ ) with the rest composed by Proteobacteria (0.13-32.9\%), Actinobacteria $\quad(0.11-30.5 \%) \quad$ and Bacteroidetes $(0.02-22.4 \%)$. The most abundant genera belong to endogenous milk microflora such as Lactobacillus, Pediococcus, Lactococcus, and
Enterococcus and contaminants such as Acinetobacter, Chryseobacterium, and Staphylococcus.

The heatmap reported in Figure 2A illustrates the distribution of the most abundant genera in all samples. The clusterization of samples on the top of Figure 2A, based on their bacterial composition, clearly showed the similarity between communities from the same malga. The Principal Coordinates Analysis (PCoA) reported in Figure 2B confirms the similarity in composition of the community in cheese produced in the same malga, using the same milk. This result demonstrates that the addition of NMC, while ameliorating hygienic conditions, does not reduce the diversity between cheese communities from different malga,
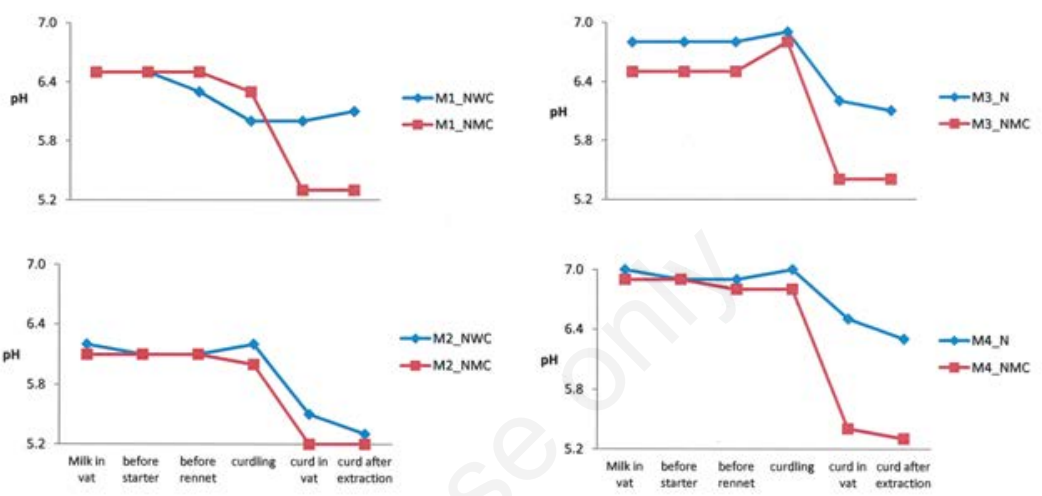

A)

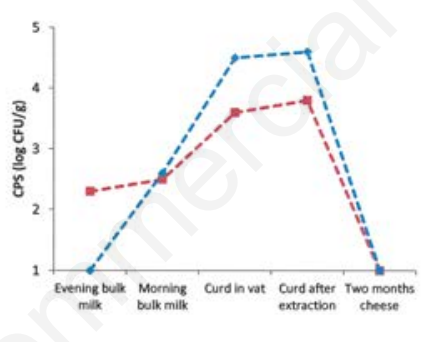

B)

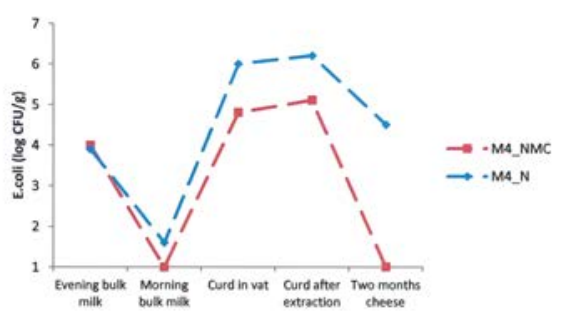

Figure 1. $\mathrm{pH}$ values of the two cheesemaking in the four malga (A), CPS counts (B) and E.coli counts (C) in the two cheesemaking of M4.

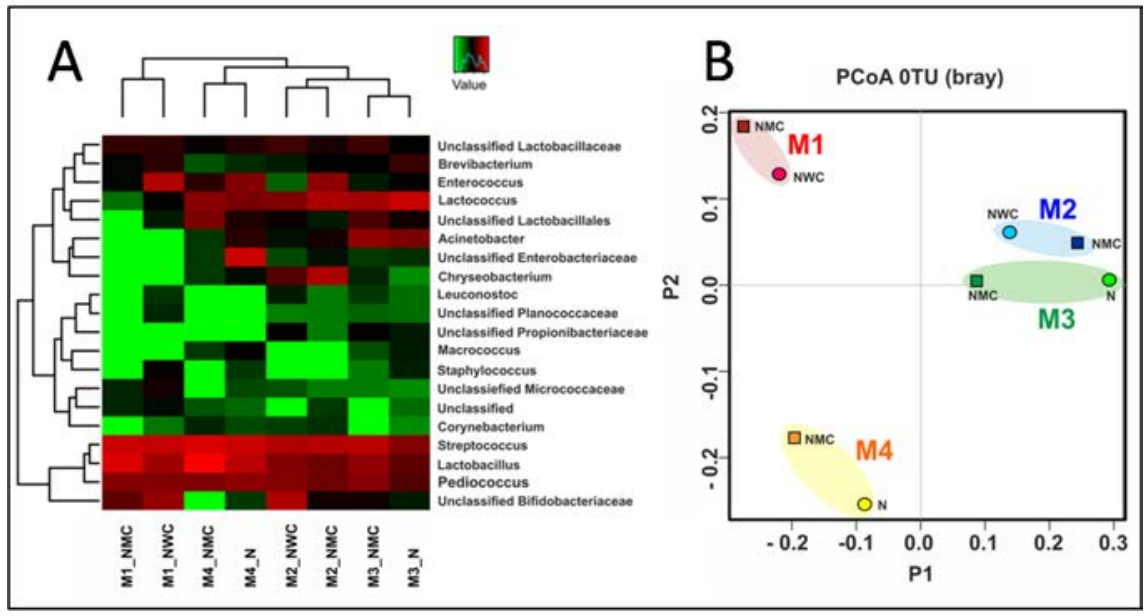

Figure 2. Distribution of the most abundant genera and clusterization of cheese samples based on their bacterial composition (A) and Principal Coordinates Analysis (PCoA) representing the $\alpha$-diversity among the cheese samples (B). 
Table 2 Distribution of the NMC OTUs in Malga samples.

\begin{tabular}{|c|c|c|c|c|c|c|c|c|c|c|}
\hline OTU ID & NMC & M1_NMC M1 & 1 NWC & M2_NMC & M2_NWC & M3_NMC & M3_N & M4_NMC & M4_N & taxonomy \\
\hline 816470 & 50 & 0 & 0 & 0 & 0 & 0 & 0 & 0 & 0 & $\begin{array}{l}\text { k_Bacteria; } \text { ___Firmicutes; c_Bacilli; 0_Bacillales; } \\
\text { f_Bacillaceae }\end{array}$ \\
\hline 591907 & 243 & 0 & 0 & 0 & 0 & 0 & 0 & 0 & 0 & 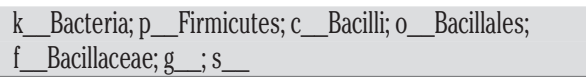 \\
\hline 760901 & 459 & 40 & 38 & 27 & 86 & 73 & 19 & 10 & 19 & $\begin{array}{l}\text { k_Bacteria; } p \_ \text {Firmicutes; c_Bacilli; 0_Lactobacillales; } \\
\text { f__Lactobacillaceae; g_; } \text { __ }\end{array}$ \\
\hline 308970 & 1 & 0 & 0 & 0 & 0 & 25 & 0 & 539 & 317 & $\begin{array}{l}\text { k_Bacteria; } \text { ___Firmicutes; c_Bacilli; } 0 \text { __Lactobacillales; } \\
\text { f__Lactobacillaceae; g__Lactobacillus; } 8 \text { __ }\end{array}$ \\
\hline 4385067 & 3 & 0 & 0 & 0 & 0 & 0 & 0 & 0 & 0 & $\begin{array}{l}\text { k_Bacteria; } p \_ \text {Firmicutes; c_Bacilli; 0__Bacillales; } \\
\text { f__Bacillaceae; } \mathrm{g} \_; s \_\end{array}$ \\
\hline 332486 & 8 & 2 & 2 & 0 & 1 & 0 & 0 & 0 & 1 & 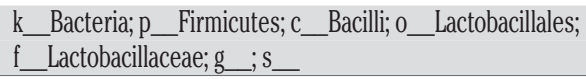 \\
\hline 625693 & 4 & 1 & 0 & 2 & 0 & 0 & 0 & 0 & 0 & $\begin{array}{l}\text { k_Bacteria; p_Firmicutes; c_Bacilli; 0_Lactobacillales; } \\
\text { f__Lactobacillaceae; g_; s__ }\end{array}$ \\
\hline 14962 & 14 & 0 & 0 & 0 & 0 & 0 & 0 & 0 & 0 & 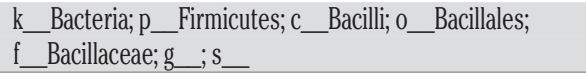 \\
\hline 746246 & 32 & 0 & 0 & 0 & 0 & 0 & 0 & 0 & 0 & $\begin{array}{l}\text { k_Bacteria; } p \_ \text {Firmicutes; c_Bacilli; 0_Bacillales; } \\
\text { f_Bacillaceae; } \mathrm{g} \text { _; } \mathrm{s} \text { __ }\end{array}$ \\
\hline 805055 & 649 & 0 & 0 & 0 & 1 & 0 & 0 & 0 & 0 & $\begin{array}{l}\text { k_Bacteria; } p \_ \text {Firmicutes; c__Bacilli; } 0 \text { _Bacillales; } \\
\text { f_Bacillaceae; } g \_; s \_\end{array}$ \\
\hline 327765 & 1 & 0 & 0 & 0 & 0 & 21 & 0 & 746 & 400 & $\begin{array}{l}\text { k_Bacteria; } p \_ \text {Firmicutes; c_Bacilli; 0_Lactobacillales; } \\
\text { f__Lactobacillaceae; g__Lactobacillus; s__ }\end{array}$ \\
\hline 573338 & 12 & 0 & 0 & 0 & 0 & 0 & 0 & 0 & 0 & 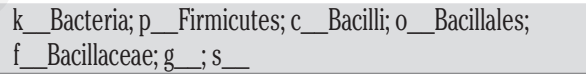 \\
\hline 260900 & 4 & 0 & 0 & 0 & 0 & 0 & 0 & 0 & 0 & $\begin{array}{l}\text { k_Bacteria; p__firmicutes; c__Bacilli; 0_Bacillales; } \\
\text { f__Bacillaceae; g_; } \mathrm{s} \text { - }\end{array}$ \\
\hline 1147446 & 3 & 0 & 0 & 0 & 0 & 0 & 0 & 0 & 0 & $\begin{array}{l}\text { k_Bacteria; } p \text { __Firmicutes; c_Bacilli; 0_Bacillales; } \\
\text { f_Bacillaceae; g_; ___ }\end{array}$ \\
\hline 4480185 & 18 & 0 & 0 & 0 & 0 & 0 & 0 & 0 & 0 & $\begin{array}{l}\text { k_Bacteria; P_Firmicutes; c__Bacilli; 0_Bacillales; } \\
\text { f__Bacillaceae; g_; } s \text { _ }\end{array}$ \\
\hline 1550056 & 12 & 0 & 0 & 0 & 0 & 0 & 0 & 0 & 0 & 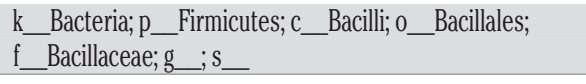 \\
\hline 4429553 & 8 & 0 & 1 & 0 & 0 & 1 & 0 & 0 & 1 & $\begin{array}{l}\text { k_Bacteria; p_Firmicutes; c_Bacilli; 0__Lactobacillales; } \\
\text { f__Lactobacillaceae; g_;s__ }\end{array}$ \\
\hline 554916 & 9 & 0 & 0 & 0 & 0 & 0 & 0 & 0 & 0 & 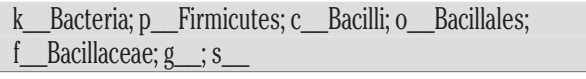 \\
\hline 1082539 & 1 & 481 & 622 & 134 & 452 & 533 & 47 & 530 & 550 & $\begin{array}{l}\text { k_Bacteria; } p \_ \text {Firmicutes; c_Bacilli; 0_Lactobacillales; } \\
\text { f__Streptococcaceae; g_Streptococcus; } s \_\end{array}$ \\
\hline 398350 & 3 & 0 & 0 & 0 & 0 & 0 & 0 & 0 & 0 & 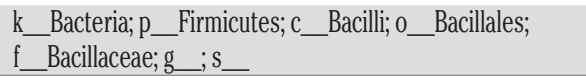 \\
\hline 355695 & 6 & 0 & 0 & 0 & 0 & 0 & 0 & 0 & 0 & 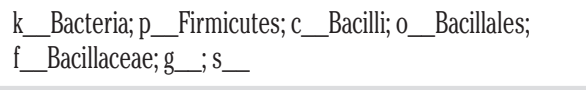 \\
\hline 4386115 & 5 & 0 & 0 & 0 & 0 & 0 & 0 & 0 & 0 & 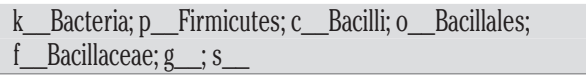 \\
\hline 4389594 & 4 & 1 & 0 & 1 & 1 & 0 & 0 & 0 & 0 & $\begin{array}{l}\text { k__Bacteria; } p \_ \text {Firmicutes; c_Bacilli; 0_Lactobacillales; } \\
\text { f__Lactobacillaceae; g_; s__ }\end{array}$ \\
\hline 587574 & 3 & 0 & 0 & 0 & 0 & 0 & 0 & 0 & 0 & 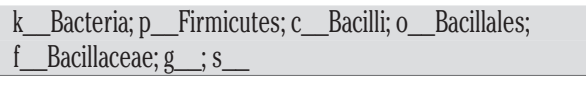 \\
\hline 139137 & 4 & 0 & 0 & 0 & 0 & 0 & 0 & 0 & 0 & 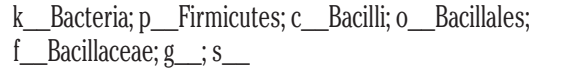 \\
\hline 252995 & 3 & 0 & 0 & 0 & 0 & 0 & 0 & 0 & 0 & $\begin{array}{l}\text { k__Bacteria; } p \_ \text {Firmicutes; c__Bacilli; } \\
\text { o__Bacillales;f_Bacillaceae; } g \_; s \_\end{array}$ \\
\hline 4333556 & 10 & 0 & 0 & 0 & 0 & 0 & 0 & 0 & 0 & $\begin{array}{l}\text { k_Bacteria; p_Firmicutes; c__Bacilli; 0__Bacillales; } \\
\text { f__Bacillaceae; } \text { __; __ }\end{array}$ \\
\hline 816219 & 102 & 0 & 0 & 0 & 0 & 0 & 0 & 0 & 0 & $\begin{array}{l}\text { k_Bacteria; } p \text { __Firmicutes; c_Bacilli; 0_Bacillales; } \\
\text { f__Bacillaceae; } g \_; s \_ \text {. }\end{array}$ \\
\hline
\end{tabular}

Continued on next page. 
Table 2. Continued from previous page.

\begin{tabular}{|c|c|c|c|c|c|c|c|c|c|c|}
\hline OTU ID & NMC & M1_NMC M1 & 1_NWC & M2_NMC & M2_NWC & M3_NMC & MB_N & M4_NMC & M4_N & taxonomy \\
\hline 366926 & 3 & 0 & 0 & 0 & 0 & 0 & 0 & 0 & 0 & 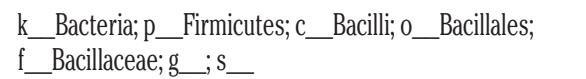 \\
\hline 160548 & 2697 & 269 & 285 & 229 & 483 & 441 & 192 & 53 & 96 & $\begin{array}{l}\text { k_Bacteria; p_Firmicutes; c_Bacilli; 0_LLactobacillales; } \\
\text { f__Lactobacillaceae; g__Pediococcus; } s \text { __ }\end{array}$ \\
\hline 2874742 & 4 & 0 & 0 & 0 & 0 & 0 & 0 & 0 & 0 & 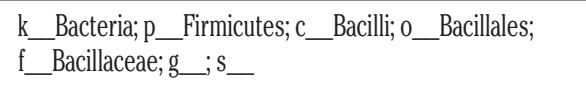 \\
\hline 218254 & 29 & 0 & 0 & 0 & 0 & 0 & 0 & 0 & 0 & $\begin{array}{l}\text { k__Bacteria; } \mathrm{p} \text { _Firmicutes; c__Bacilli; } 0 \text { __Bacillales; } \\
\text { f__Bacillaceae; __; __ }\end{array}$ \\
\hline 4305372 & 18 & 2 & 6 & 1 & 4 & 5 & 1 & 0 & 0 & $\begin{array}{l}\text { k__Bacteria; p_Firmicutes; c_Bacilli; 0__Lactobacillales; } \\
\text { f__Lactobacillaceae; g_; s__ }\end{array}$ \\
\hline 805735 & 9 & 1 & 1 & 0 & 1 & 1 & 1 & 0 & 3 & $\begin{array}{l}\text { k__Bacteria; p_Firmicutes; c_Bacilli; } 0 \text { __Lactobacillales; } \\
\text { f_L_Lactobacillaceae; g_;s__ }\end{array}$ \\
\hline 4371645 & 28 & 3 & 3 & 6 & 8 & 10 & 6 & 0 & 0 & 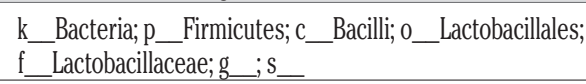 \\
\hline
\end{tabular}

thereby preserving the typicality of products from each malga. The $\alpha$-diversity index (Observed species in Table 1) describing the level of microbial biodiversity obtained for each sample confirms such result.

The complete list of the OTU identified in the NMC is reported in Table 2. Summarizing the OTUs in higher taxonomic categories, the NMC contains a predominance of Lactobacillaceae (about the $72 \%$ of the population), including the genus Pediococcus spp, which represents $60 \%$ of the microbial population. Based on results from RAPD analysis performed during strain selection for NMC production (Andrighetto et al. 2002; Paternolli et al. 2014), a prevalence of the genus Streptococcus spp among Lactobacillaceae was expected. NGS-based microbial profiling did not show the presence of Streptococcus suggesting that the RAPD approach likely misclassified Pediococcus strains as Streptococcus. The rest of the bacterial population was composed by Bacillacee (about 26\%), which likely represent a contamination deriving from the milk used to produce NMC. Pediococcus has been already reported as the dominant bacteria in malga milk, together with Lactobacillus (Pediococcus pentosaceus and Lactobacillus paracasei) (Carafa et al., 2015). Despite its incorrectly defined composition, the NMC demonstrated to have a good performance in cheesemaking. On the other hand, the obtained results highlight that the use of DNA sequencing is essential to improve accuracy and reproducibility in starter production.

Comparing the NMC composition at OTU level (each OTU represents a strain) with the OTU distribution in cheese samples demonstrates that none of the strains deriving from NMC became predominant in cheese (see Table 2) and the genus Pediococcus is present in all the cheese samples (with or without the addition of NMC). As a matter of fact, the addition of NMC has different effects in each malga (the $\alpha$-diversity index in M1 and M4 slightly decreases and in M2 and M3 slightly increases) suggesting that the starter microflora does not affect the composition of the cheese bacterial community, which largely depends on the endogenous microflora of milk.

\section{Conclusions}

Alpine dairy products are generally manufactured from not pasteurized raw milk, in working environments that often do not ensure good hygiene practices. As a consequence, more frequently than other productions, such products might represent a risk for public health because they could be contaminated with food-borne pathogens. While it might not be always possible to increase the level of hygienic practices, simple modifications of the technological process such as the use of NWC or selected NMC might help reducing the risks associated to the consumption of raw cow's milk cheese. In fact, the present study shows that the addition of NMC, prepared using endogenous technologically active strains in raw milk cheesemaking promotes the acidification process and drives the primary fermentation. To this end, malga cheesemakers need guidelines to produce NWM, otherwise it can happen as in M1_NWM where $\mathrm{pH}$ did not decrease below 6 . The results obtained here confirm that quality of raw milk and hygiene of work areas remain critical to determine cheese quality and safety. It was shown that adequate growth of lactic bacteria during dairy farming contributes to the control of the multiplication of potentially pathogenic bacteria, with particular reference to enterotoxin-producing staphylococci, and can help in the production of safer cheese (Bennett et al., 1983; Cretenet et al., 2011, Schelin et al., 2011). Moreover, even when starting from milk of poor hygienic quality, as in the case of M3 and M4, the addition of NMC led to substantial reduction of $E$. coli microbial load in two-months ripened cheese. The study also demonstrates that addition of NMC produced with selected indigenous strains does not significantly affect the cheese microflora, and NMC may be used without losing the typicality of cheese from individual malga farms.

\section{References}

Andrighetto C, Borney F, Barmaz A, Stefanon B, Lombardi A, 2002. Genetic diversity among Streptococcus thermophilus isolated from Italian traditional cheese. Int Dairy J 12:141-4.

Bennett, RW, Amos, WT. 1983. Staphylococcus aureus growth and toxin production in imitation cheese. $\mathrm{J}$ Food Sci 48:1670-3.

Bokulich, NA, Subramanian S, Faith JJ, Gevers D, Gordon JI, Knight R, Mills DA, Caporaso JG, 2013. Quality-filtering vastly improves diversity estimates from Illumina amplicon sequencing. Nat Methods 10:57-59.

Brooks JC., Martinez B, Stratton J, Bianchini A, Krokstrom R, Hutkins R, 2012. Survey of raw milk cheeses for microbiological quality and prevalence of foodborne pathogens. Food 
Microbiol 31:154-8.

Caporaso JG Caporaso JG, Kuczynski J, Stombaugh J, Bittinger K, Bushman FD, Costello EK, Fierer N, Peña AG, Goodrich JK, Gordon JI, Huttley GA, Kelley ST, Knights D, Koenig JE, Ley RE, Lozupone CA, McDonald D, Muegge BD, Pirrung M, Reeder J, Sevinsky JR, Turnbaugh PJ, Walters WA, Widmann J, Yatsunenko T, Zaneveld J, Knight R, 2010. QIIME allows analysis of high-throughput community sequencing data. Nat Methods 7:335-6.

Carafa I, Nardin T, Larcher R, Viola R, Tuohy K, Franciosi E, 2015. Identification and characterization of wild lactobacilli and pediococci from spontaneously fermented Mountain cheese. Food Microbiol 48:123-32.

Carafa I, Clementi F, Tuohy K, Franciosi E, 2016. Microbial evolution of traditional mountain cheese and characterization of early fermentation cocci for selection of autochtonous dairy starter strains. Food Microbiol 53:94-103.

Cretenet M, Nouaille S, Thouin J, Rault L, Stenz L, Francois P, Hennekinne JA, Piot M, Maillard MB, Fauquant J, Loubière P, Le Loir Y, Even S, 2011. Staphylococcus aureus virulence and metabolism are dramatically affected by Lactococcus lactis in cheese matrix. Environ Microbiol Rep 3:340-51.

De Buyser ML, Dufour B, Maire M, Lafarge V, 2001. Implication of milk and milk products in foodborne diseases in France and in different industrialized countries. Int J Food Microbiol 67:1-17.

Duquenne M, Fleurot I, Aigle M, darrigo C, borezée-Durant E, Derzelle S, Bouix M, Deperrois-Lafarge V, Delacroix-Buchet A, 2010. Tool for Quantification of Staphylococcal Enterotoxin Gene in Cheese. App Env Microbiol 76:136774.

European Commission, 2004. Regulation of the European Parliament and of the Council of 29 April 2004 laying down specific hygiene rules for the hygiene foodstuffs, 853/2004/CE. In: Official Journal, L 139/55, 30/04/2004

European Commission, 2005. Commission Regulation (EC) of 15 November 2005 on microbiological criteria for foodstuffs. 2073/2005/CE. In: Official Journal. L 338/1. 22/12/2005.

European Food Safety Authority (EFSA), 2014. The European Union Summary Report on Trends and Sources of Zoonoses, Zoonotic Agents and Food- borne Outbreaks in 2012. EFSA J, 12(2), 3547.

European Screening Method of the European Union-Reference Laboratory for Coagulase Positive Staphylococci, including Staphylococcus aureus, $5^{\text {th }}$ ed. 2010. Ostyn A, Prufer AL, Papinaud J, Hennekinne J-A, Assere A, Lombard b. Detection of staphylococcal enterotoxins types SEA to SEE in all types of food matrices. EU-RL CPS; ANSE; Maisons-Alfort, France (1-12).

ISO, 1999. Meat and meat products - measurements of $\mathrm{pH}$ - reference method. ISO Norm 2917:1999(E). International Standardization Organization ed., Geneva, Switzerland.

ISO, 2001. Microbiology of food an animal feeding stuffs - horizontal method for the enumeration of beta-glucuronidasepositive Ec - part 2: colony-count technique at $44^{\circ} \mathrm{C}$ using 5-bromo-4-chloro3-indolyl-beta-D-glucuronide. ISO Norm 16649-2:2001. International Standardization Organization ed., Geneva, Switzerland.

ISO, 2003. Microbiology of food and animal feeding stuffs - horizontal method for the enumeration of coagulase-positive staphylococci (Staphylococcus aureus and other species). Part 2: technique using rabbit plasma fibrinogen agar medium ISO Norm 68882:1999/Amd.1:2003. International Standardization Organization ed., Geneva, Switzerland.

ISO, 2014. Microbiology of food and animal feeding stuffs - determination of water activity. ISO Norm 21807:2004(E). International Standardization Organization ed., Geneva, Switzerland.

ISO, 2013. Microbiology of the food chain - Horizontal method for the enumeration of microorganism - part 1: colony count at 30 degrees $\mathrm{C}$ by the pour plate technique.ISO Norm 4833-1:2013. International Standardization Organization ed., Geneva, Switzerland.

ISO, 2013. Microbiology of food and animal feeding stuffs - General requirements and guidance for microbiological examinations. Amendment 1. ISO Norm 7218:2007/Amd.1:2013(E). International Standardization Organization ed., Geneva, Switzerland.

Kousta M, Mataragas M, Skandamis P, Drosinos EH, 2010. Prevalence and sources of cheese contamination with pathogens at farm ad processing levels. Food Control 21:805-15.
Lucchini R, 2015. Quanto sono sicuri i formaggi delle nostre malghe. Esperienze pratiche e indicazioni per la produzione. L'allevatore Trentino 3:20-5

McSweeney PLH (Ed), 2009. Cheese problems solved. Cambridge: Woodhead publishing limited, pp 119-123, 131132, 140-144.

Montel MC, Buchin S, Mallet A, DelbesPaus C, Vuitton DA, Desmasures N, Berthier F, 2014. Traditional cheeses: rich and diverse microbiota with associated benefits. Int $\mathrm{J}$ Food Microbiol. 177:136-54.

Mucchetti G, Neviani E 2006. Microbiologia e tecnologia lattierocasearia. Qualità e sicurezza. Ed. Tecniche Nuove, Milano, 400.

Nadkarni, M A, Martin, F E, Jacques, N A, Hunter, N, 2002. Determination of bacterial load by real-time PCR using a broad-range (universal) probe and primers set. Microbiology 148:257-66.

Paternolli S, Pedrolli I, Paolazzi G, Andrighetto C, Lombardi A, Lucchini R, 2014. Sviluppo di colture batteriche autoctone con attitudine casearia e competitiva nei confronti i patogeni per la valorizzazione dei prodotti caseari d'alpeggio: applicazione in campo. Atti XXIV Convegno AIVI Bologna 10-12 settembre 2014 pp 21-22

Povolo M, Pelizzola V, Passolungo L, Biazzi E, Tava A, Contarini G, 2013. Characterization of two AgrostisFestuca alpine pastures and their influence on cheese composition. J Agric Food Chem 61:447-55.

Presser KA, Ratkowsky PA, Ross T 1997 Modelling the growth rate of $\mathrm{E}$ coli as a function of $\mathrm{pH}$ and lactc acid concentration. Appl Environ Microbiol 63:235560.

Rosengren A, Fabricius A, Guss B, Sylven S, Lindqvist R, 2010. Occurrence of foodborne pathogens and characterization of Staphylococcus aureus in cheese produced on farm-diaries Int $\mathrm{J}$ Food Microbiol 144:263-9.

Schelin J, Wallin-Carlquist N, Cohn MT, Lindqvist R, Barker GC, Radstrom P, 2011. The formation of Staphylococcus aureus enterotoxin in food environments and advances in risk assessment Virulence 2:580-92.

Topisirovic L, Kojic M, Fira D, Golic N, Strahinic I, Lozo J, 2006. Potential of lactic acid bacteria isolated from specific natural niches in food production and preservation. Int $\mathrm{J}$ Food Microbiol 127:230-5. 